\title{
Effect of Reaction Time and Catalyst Feed Rate towards Carbon Nanotubes Yields and Purity by Using Rotary Reactor
}

(Kesan Tindak Balas Masa dan Kadar Suapan Pemangkin ke Arah Hasil dan

Ketulenan Karbon Nanotiub dengan Menggunakan Reaktor Putar)

\author{
RABITA FiRDAUS, NUR SYAHIDAH AFANDI, MEHRNOUSH KHAVARIAN \& ABDUl RAHMAN MOHAMED*
}

\begin{abstract}
Continuous production of multi-walled carbon nanotubes (MWCNTS) by chemical vapor deposition (CVD) method was investigated in a rotary reactor. The aim of the study was to investigate the effect of catalyst feeding rate and reaction time on the MWCNTs production yield and purity. Bimetallic Co-Mo supported on MgO was used for the growth of MWCNTs and methane gas was used as the carbon precursor. The results indicated that the highest yield of MWCNTs production was attained at the reaction time of $180 \mathrm{~min}$ and catalyst feeding rate of $100 \mathrm{mg} / \mathrm{min}$; this sample also had the highest purity (99.16\%). SEM and TEM analyses of the synthesized product confirmed that most of the MWCNTs were sinuous and entangled with a uniform diameter. Raman spectroscopy indicated that the as-produced MWCNTs were mostly graphitic with few disordered carbon and impurities. The results highlighted that synthesized MWCNTs were highly pure which eliminates the need for MWCNTS purification process.
\end{abstract}

Keywords: Carbon nanotubes; catalyst feed rate; chemical vapor deposition (CVD); reaction time

ABSTRAK

Pengeluaran tiub nano karbon berbilang dinding (MWCNTs) secara berterusan melalui proses penguraian wap bermangkin (CVD) telah dijalankan dalam sebuah reaktor berputar. Tujuan kajian ini adalah untuk mengkaji kesan kadar kemasukan pemangkin dan kadar masa reaksi terhadap hasil pengeluaran MWCNTs dan ketulenan. Gabungan dwi logam Co-Mo tersokong di atas $\mathrm{MgO}$ telah digunakan untuk pertumbuhan MWCNTs dan gas metana digunakan sebagai prekursor karbon. Keputusan menunjukkan bahawa pengeluaran tertinggi pengeluaran MWCNTs dicapai pada kadar masa reaksi 180 min dan kadar kemasukan pemangkin 100 mg/min; sampel ini juga berketulenan tinggi (99.16\%). Analisis SEM dan TEM terhadap produk yang disintesis itu mengesahkan bahawa kebanyakan MWCNTs adalah bergabung dan terikat dengan diameter seragam. Spektroskopi Raman menunjukkan bahawa MWCNTs yang dihasilkan kebanyakannya adalah grafit dengan sedikit karbon dan bendasing. Keputusan menunjukkan bahawa MWCNTs yang disintesis adalah sangat tulen dan tidak memerlukan proses penulenan MWCNTS.

Kata kunci: Kadar kemasukan pemangkin; kadar masa reaksi; karbon nanotiub; penguraian wap bermangkin

\section{INTRODUCTION}

Carbon nanotubes (CNTs) have gained considerable attention among researchers due to their extraordinary mechanical and unique electronic properties. Large scale production of high quality CNTs is highly demanded since CNTs have many applications in super conduction transmission (Tran et al. 2016), polymer reinforcements (Peng et al. 2014), electron field emission (Sridhar et al. 2014), drug delivery systems (Mehra et al. 2015), energy storage (Zhang et al. 2013) and environmental fields application (Qu et al. 2013). Generally, there are few typical methods for the synthesis of CNTs including electrolysis ( $\mathrm{Lu}$ et al. 2015), laser ablation (Rouleau 2014), pyrolysis (Vilatela et al. 2015), arc discharge (Chaudhary et al. 2013) and chemical vapor deposition (CVD) (Rouleau 2014). Among these techniques, CVD approaches have been used commercially in order to achieve large scale production of CNTs at relatively low cost (Monthioux 2011). CVD has emerged as an advanced engineering technique in many industrial sectors. Moreover, CVD method gives an additional benefit as it enables the deposition of carbon on many alloys and their different compounds like carbides, oxides and nitride (Hamedani et al. 2016). Even though CVD applies a simple principle, still the precisely controlled growth of CNTs remains a complex challenge. This is because many different parameters are involved in the process that influence the growth of CNT, such as catalyst concentration, reaction time, and temperature, flow rate of carbon precursor and catalyst activity. Ming et al. (2016) reported the effect of reaction temperature on CNT yield and morphology grown on copper loaded nickel nanoparticles by CVD method with methane as the carbon source. They found that increase of temperature had an encouraging the effect on CNT growth. Besides, the SEM images show that the CNT products were homogeneously 
distributed on the surface of copper powder. DündarTekkaya and Karatepe (2015) investigated the effect of weight ratio, catalyst type and reaction time on the yield of single-wall carbon nanotubes (SWNTs) synthesized via CVD of acetylene at $800^{\circ} \mathrm{C}$. They notice that the carbon efficiency increase as prolong the reaction time from 30 to $60 \mathrm{~min}$. But, increase in weight ratio from 1:100 to 10:100 result in low carbon efficiency. Mageswari et al. (2014) conducted a study on the influence of reaction temperature and flow rate on the yield of multi-walled carbon nanotubes (MWNTs) synthesized via spray pyrolysis of Cymbopogen fexuous oil and they found that the CNT yield were low as the flow rate less that 20 $\mathrm{mL}$ per hour. Thus, they also concluded that the optimum operating conditions for synthesis of CNTs were $650^{\circ} \mathrm{C}$ with the flow rate of $20 \mathrm{~mL}$ per hour. Although numbers of factors that affect the CNTs production yield have been investigated by many researchers, yet, the effect of certain parameters has remained unclear. Particularly, the effect of catalyst feeding rate on the yield of CNT in continuous operation has not been evidently investigated and implied yet. In this study, a horizontally oriented rotary reactor was used for continuous production of MWCNTs and the influence of catalyst feeding rate and reaction time on the MWCNTS production yield and quality was studied. The morphology and purity of the synthesized MWCNTs was also investigated through several analyses including SEM-EDX, TEM, Raman, TGA and XPS.

\section{MATERIALS AND METHODS}

The catalyst used in this study was $\mathrm{Co}-\mathrm{Mo} / \mathrm{MgO}$. The bi-metallic catalyst was prepared by sol-gel method following the procedure presented by (Yeoh et al. 2012). In brief, calculated amount of catalyst precursors Co $\left(\mathrm{NO}_{3}\right)_{2} \cdot 6 \mathrm{H}_{2} \mathrm{O}$ (Sigma-Aldrich, $\left.\geq 98 \%\right), \mathrm{Mg}\left(\mathrm{NO}_{3}\right)_{2} \cdot 6 \mathrm{H}_{2} \mathrm{O}$ (Sigma-Aldrich, $\geq 98 \%$ ), and $\left(\mathrm{NH}_{4}\right)_{6} \mathrm{Mo}_{7} \mathrm{O}_{24} \cdot 4 \mathrm{H}_{2} \mathrm{O}$ (Sigma-Aldrich, 99.98\%) were dissolved in deionized water and then citric acid was added to the homogenous mixture. The mixture was continuously stirred and heated around $90^{\circ} \mathrm{C}$ for an hour until a gel-like mixture was appeared. Later, the gel mixture was baked at $120^{\circ} \mathrm{C}$ overnight and then ground into fine powder. The resulting powder was calcined in air at $550^{\circ} \mathrm{C}$ for $2 \mathrm{~h}$. MWCNTs production was conducted continuously in a horizontal rotary reactor at atmospheric pressure. Figure 1 shows a schematic diagram of the rotary reactor. Firstly, the prepared $\mathrm{Co}-\mathrm{Mo} / \mathrm{MgO}$ catalyst powder was loaded into the $\mathrm{V}$-shaped hopper. The tubular reactor was pre-heated to the desired reaction temperature of $850^{\circ} \mathrm{C}$ under a flow of nitrogen. Once the desired temperature was reached, mixture of equal volumetric ratio of methane to nitrogen was constantly flowed into the reactor at a total flow rate of $1.0 \mathrm{~L} / \mathrm{min}$, while the catalyst powder was also fed continuously into the reactor. Revolving coil spring installed at the middle of the tubular reactor enabled effective control of the contact time between catalyst and reactant gas. The $\mathrm{Co}-\mathrm{Mo} / \mathrm{MgO}$ catalyst was conveyed to the reactor by gravity and its movement along the reactor was controlled by the rotational speed and degree of inclination of the rotating tube. The effluent carbon deposits were collected from the product reservoir which was placed at the lower end of the reactor. In this work, the effects of catalyst feeding rate $(100-500 \mathrm{mg} / \mathrm{min})$ and retention time (60-180 $\mathrm{min}$ ) on the MWCNTs production yield was considered. The structural morphology of the synthesized MWCNTs was studied using transmission electron microscopy (TEM; Philips, model CM12) and scanning electron microscopy (SEM; LEICA Cambridge S360) was used to analyze the surface topology and morphology of the catalyst and MWCNTs sample. Raman spectroscopy (Renishaw, inVia Raman microscope) was used to determine the degree of graphitization and defect level of the MWCNTs, while thermogravimetric (TG) analyzer (TGA Instruments, SDT Q600) under air flow of $150 \mathrm{~mL} / \mathrm{min}$ and temperature range of $10-900^{\circ} \mathrm{C}$ was used in order to study the yield and purity of the produced MWCNTs. The purity of MWCNTs was determined directly from the TG curve and the productivity of catalyst performance in the MWCNTs synthesis was defined in terms of the carbon yield as shown in (1):

$$
\text { Carbon Yield }=\frac{\% \text { weight loss by carbon oxidation }}{\% \text { of residue after oxidation }} \times 100 \%
$$

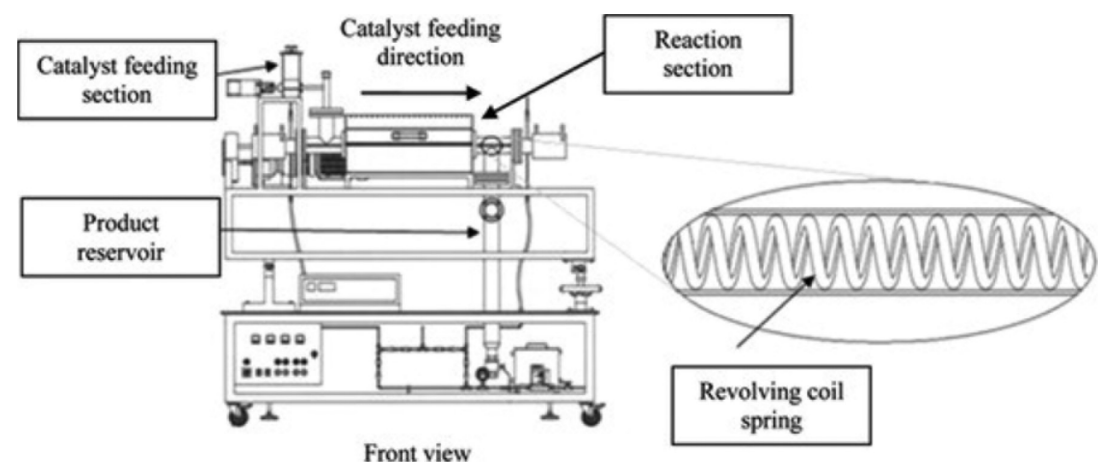

FIGURE 1. Schematic diagram of the horizontal rotary reactor to synthesis of CNTs (Yeoh et al. 2012) 


\section{RESULTS AND DISCUSSION}

\section{CATALYST CHARACTERIZATION}

The composition of the Co-Mo catalyst supported on $\mathrm{MgO}$ was determined using SEM-EDX analysis. The EDX spectrum as depicted in Figure 2(a) clearly indicated the presence of $\mathrm{Co}, \mathrm{Mo}, \mathrm{Mg}$ and $\mathrm{O}$. The surface morphology of the developed catalyst was assessed by SEM analysis; the SEM micrograph as exhibited in Figure 2(b) shows a 'bird's-nest' structure. The catalyst surface was also porous which facilitated the diffusion of feed gas into the catalyst structure and growth of carbon material. The result of SEMEDX analysis confirmed the successful synthesis of porous $\mathrm{Co}-\mathrm{Mo} / \mathrm{MgO}$ catalyst by sol-gel method.

\section{EFFECT OF CATALYST FEEDING RATE AND REACTION TIME ON MWCNTS YIELD}

The effect of reaction time on the MWCNTs production yield and purity was investigated with different reaction time between 60 and $180 \mathrm{~min}$. The weight loss (TG) curves of synthesized MWCNTs and yield of carbon production at different reaction times are presented in Figure 3(a) and 3(b), respectively. Increasing the reaction time from 60 to 150 min made a rapid increase in carbon due to the longer exposure of carbon precursor $\left(\mathrm{CH}_{4}\right)$ with catalyst. However, at this prolonged reaction time the MWCNTs growth rate slowed down due to some possible drops in catalytic activity. Similarly, extending the reaction time led to the higher carbon production as more methane molecules were reacted with the catalyst for MWCNTs growth (Kamalakar et al. 2002). Effect of catalyst feeding rate on the yield and purity of MWCNTs was studied in the 100 to $500 \mathrm{mg} / \mathrm{min}$ and the results are projected in Figure 4. From the TG curves in Figure 4(a), with increase of catalyst feeding rate the amount of residue left after product oxidation increased, implying a lower purity of MWCNTs product. At the catalyst feeding rate of $500 \mathrm{mg} /$ min, the MWCNTs product had the lowest carbon yield which was $705.8 \%$. Figure 4(b) indicates that increase of catalyst feeding rate resulted in an abrupt decrease in carbon yield. The highest carbon yield was achieved at catalyst feeding rate of $100 \mathrm{mg} / \mathrm{min}$. To understand why the CNT yield obtained was low at a higher feed rate of catalysts, the number of active sites on the surface of the catalyst must be considered. At the beginning of the CVD process, there were a lot of fresh active catalytic sites. Each active site decomposed the methane molecules to form MWCNTs. Thus, as the catalyst feed rate increased, the carbon weight decreased and less MWCNTs were formed. Besides, since the flow rate of methane was fixed at $1.0 \mathrm{~L} / \mathrm{min}$, with increase of catalyst loaded into the reactor the MWCNTs production yield decreased due to the limited availability of the carbon precursor from deposited methane to produce MWCNTs (Shukrullah et al. 2016). Based on the obtained results, the reaction time of

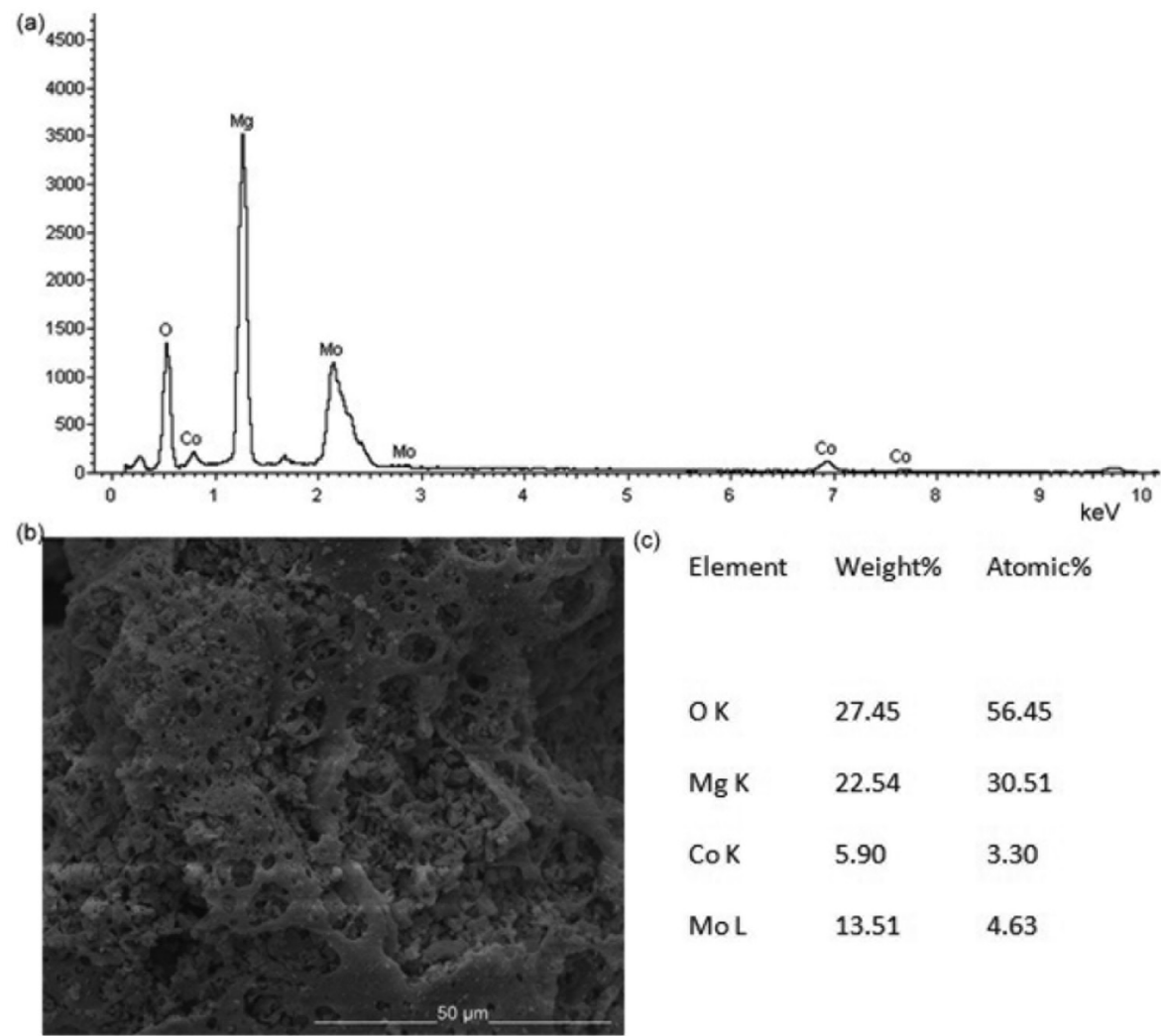

FIGURE 2. (a) EDX results of $\mathrm{Co}-\mathrm{Mo} / \mathrm{MgO}$ catalyst (b) SEM image for $\mathrm{Co}-\mathrm{Mo} / \mathrm{MgO}$ surface (c) atomic composition for each element 

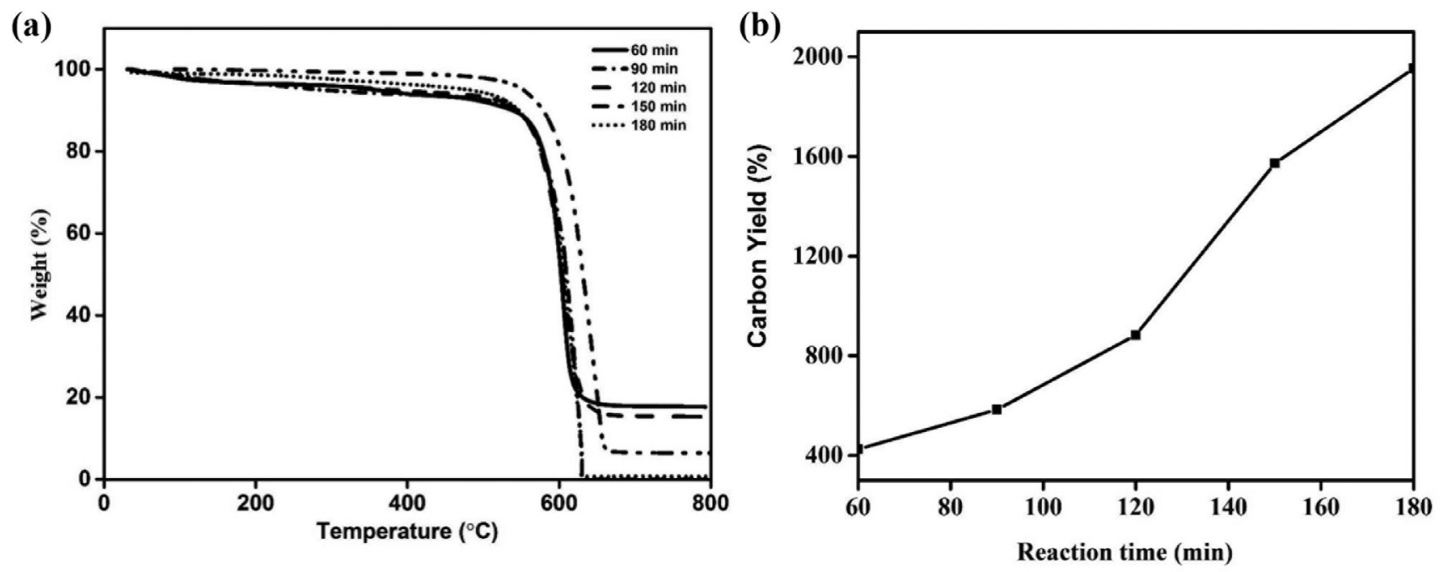

FIGURE 3. (a) Thermogravimetric curve of the as-produced CNTs during different reaction time (b) Graph plot of the CNT yield versus the reaction time

(a)

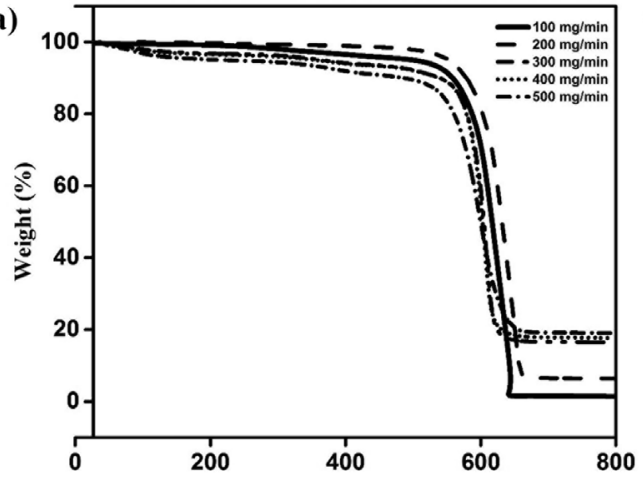

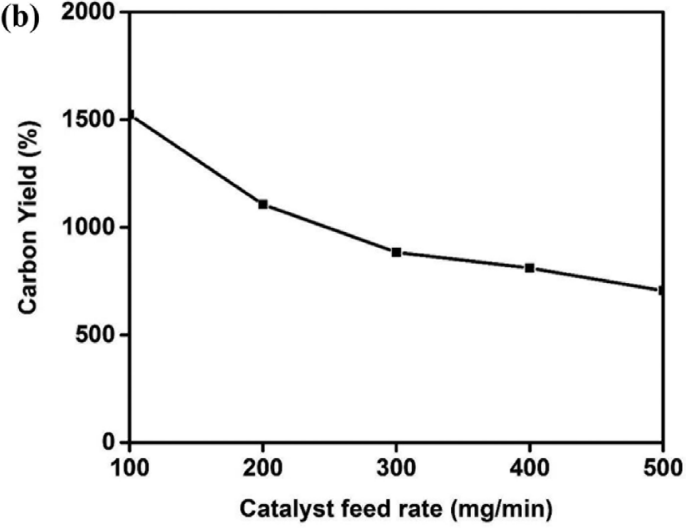

FIGURE 4. (a) Thermogravimetric curve of the as-produced MWCNTs by using different catalyst feed rate (b) Graph plot for the effect of catalyst feed rate on carbon yield

$180 \mathrm{~min}$ and catalyst feeding rate of $100 \mathrm{mg} / \mathrm{min}$ was the optimum condition to obtain the highest yield of MWCNTs with high purity.

\section{CHARACTERIZATION OF THE SYNTHESIZED MWCNTS}

\section{TEM AND SEM ANALYSES}

The TEM and SEM images of the MWCNTs sample synthesized at the temperature of $850^{\circ} \mathrm{C}$, reaction time of $180 \mathrm{~min}$ and catalyst feeding rate of $100 \mathrm{mg} / \mathrm{min}$ are illustrated in Figure 5(a)-5(c) and 5(d), respectively. The as-produced MWCNTs were sinuous and entangled, had layer structure with the length up to several micrometers $(\sim 7-9 \mu \mathrm{m})$ and were nearly uniform in diameter. The morphologies in Figure 5(a) indicate the synthesis of highly dense rope-like MWCNTs grown from the surface of catalyst cluster. Figure 5(b) shows that the MWCNTs has a closed hemispheric tip without a catalyst particle. However, there were slightly defects in the structure of the nanotube maybe due to the curvature of the graphene layers (Gulino et al. 2005). Figure 5(c) evidently showed that the MWCNTs had tip growth mechanism where the catalyst particles can be observed at the tip of the growing tubes. When the interaction is weak, then tip growth occurs (Kharlamova 2017). In this case, carbon source molecule generated from the decomposition of $\mathrm{CH}_{4}$ will deposit on the metal surface, and then the concentration gradient within the metal particles will create a driving force for diffusion of carbon into the metal particles. Then, the formation of graphitic layer occurs; generating MWCNTs. Figure 5(d) shows the SEM image of the as produced MWCNTs with bundled structure. Only a slight trace of metal catalysts can be observed in the image implying the high purity of the as synthesized MWCNTs. Therefore, purification step which is vital in catalysis application can be excluded since the produced MWCNTS had very high purity.

\section{RAMAN ANALYSIS}

In order to investigate the degree of graphitization of the produced MWNTs Raman spectroscopy was carried out. Raman spectroscopy results of MWCNTs synthesized at 180 and $60 \mathrm{~min}$ with catalyst feeding rate of $100 \mathrm{mg} / \mathrm{min}$ are shown in Figure 7(a) and 7(b), respectively. Three 

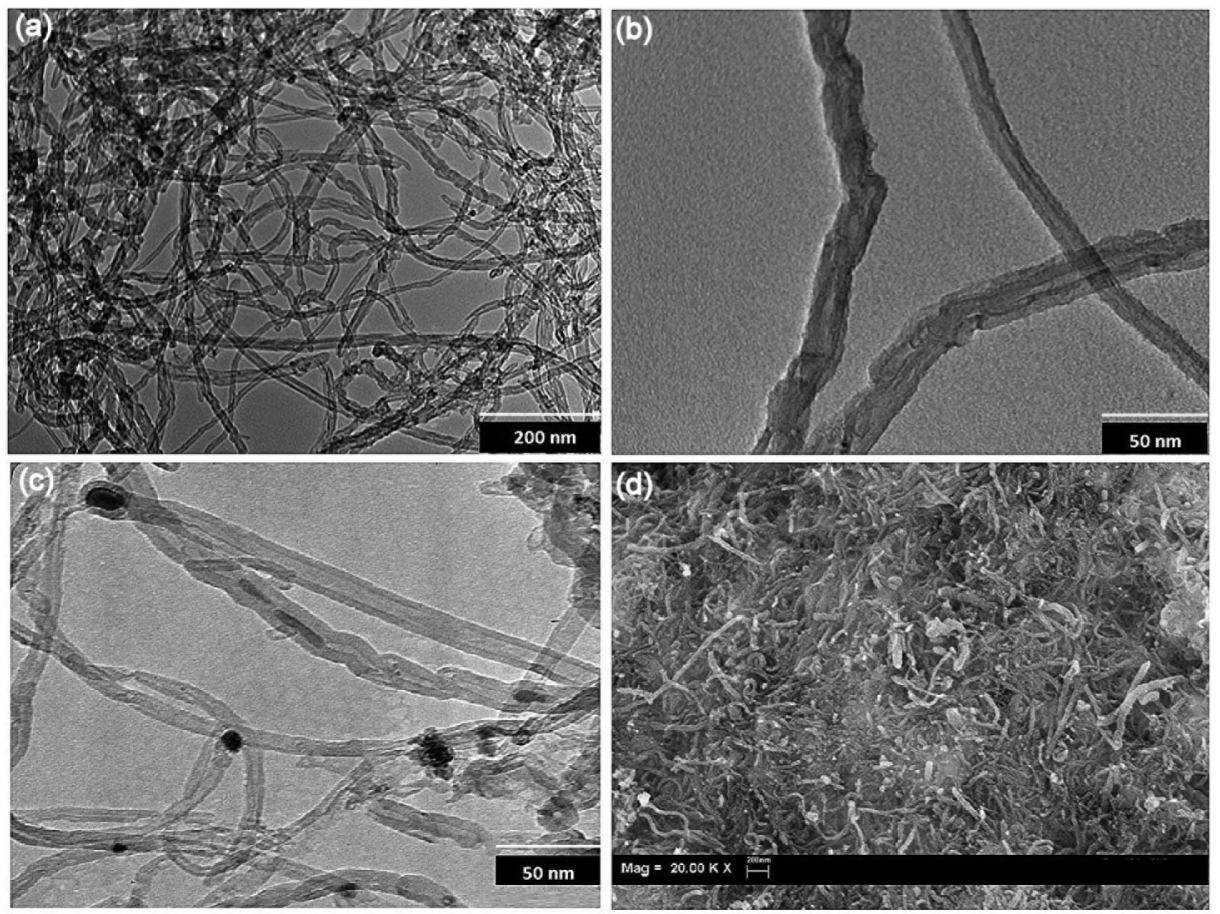

FIGURE 5. Image of the carbon deposit synthesized at optimum operating condition (a) TEM image illustrates the large crosssectional area (b) the magnification of MWCNTs at $50 \mathrm{~nm}$ (c) TEM image of the tip growth of carbon nanotubes (d) SEM image of the as-synthesized MWCNTs $\left(850^{\circ} \mathrm{C} / 180 \mathrm{~min}\right.$, catalyst feed rate of $100 \mathrm{mg} / \mathrm{min}$ and methane: nitrogen, 1:1)

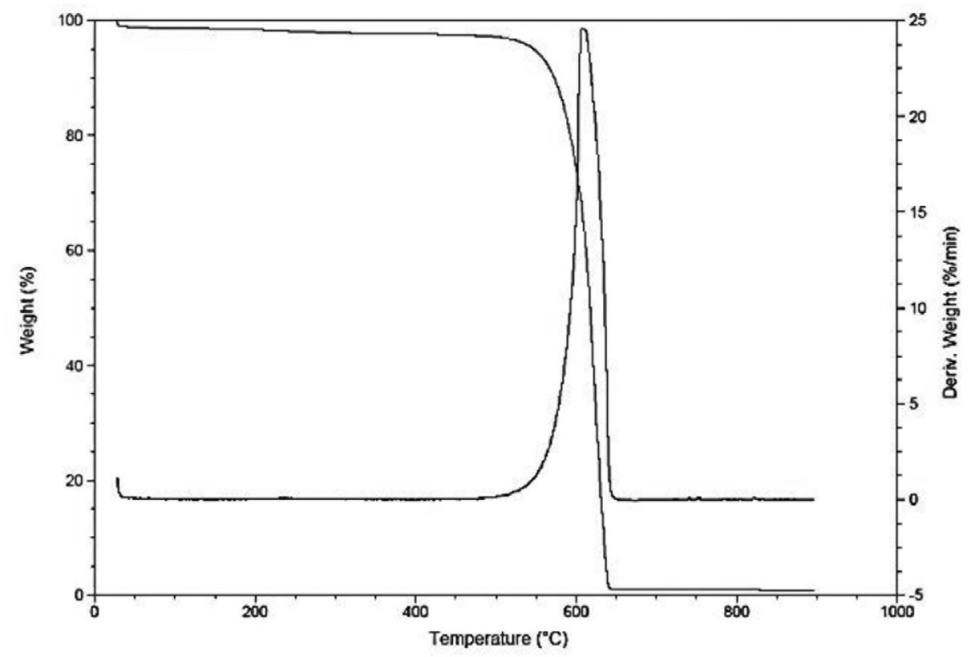

FIGURE 6. TGA and DTA curves of the synthesized CNT at temperature $850^{\circ} \mathrm{C}$ of $180 \mathrm{~min}$ and $100 \mathrm{mg} / \mathrm{min}$

major bands namely D-band, G-band, and 2D-band were observed in the Raman spectra. The D-band was located approximately at $1350 \mathrm{~cm}^{-1}$, whereas the G-band appeared at around $1583 \mathrm{~cm}^{-1}$. The ratio of $\mathrm{D}$ to $\mathrm{G}$ bands in the spectrum explains the defect and graphitic carbon formed in the MWCNTs. The 2D-band is usually used to identify the number of layers of MWCNTs. This is because the shape of 2D-band in multi-layer MWCNTs is not the same as that of SWCNTs. From the literature, the peaks are more intense and sharper for single layer compared to multi-layer CNTs (Calizo et al. 2007). From Figure 7(a), the intensity of the D-band is lower than the G-band, giving an $\mathrm{I}_{\mathrm{D}} / \mathrm{I}_{\mathrm{G}}$ ratio of 0.70 implying that the MWCNTs sample was more crystalline. This result indicates that the produced MWCNTs might contain a low level of defects and higher amount of graphitized carbon, which normally results from thermal decomposition of methane at high temperature. When the G-band splits into two peaks, it shows that there are either some impurities or surface charges in the MWCNTs (Yoon \& Cheong 2012). This condition occurs due to the limited vibrational modes of impurities which interact with the phonon modes of MWCNTs resulting in the split of G-band as shown in the Raman spectrum (Jafari et al. 2015). Figure 7(b) shows 

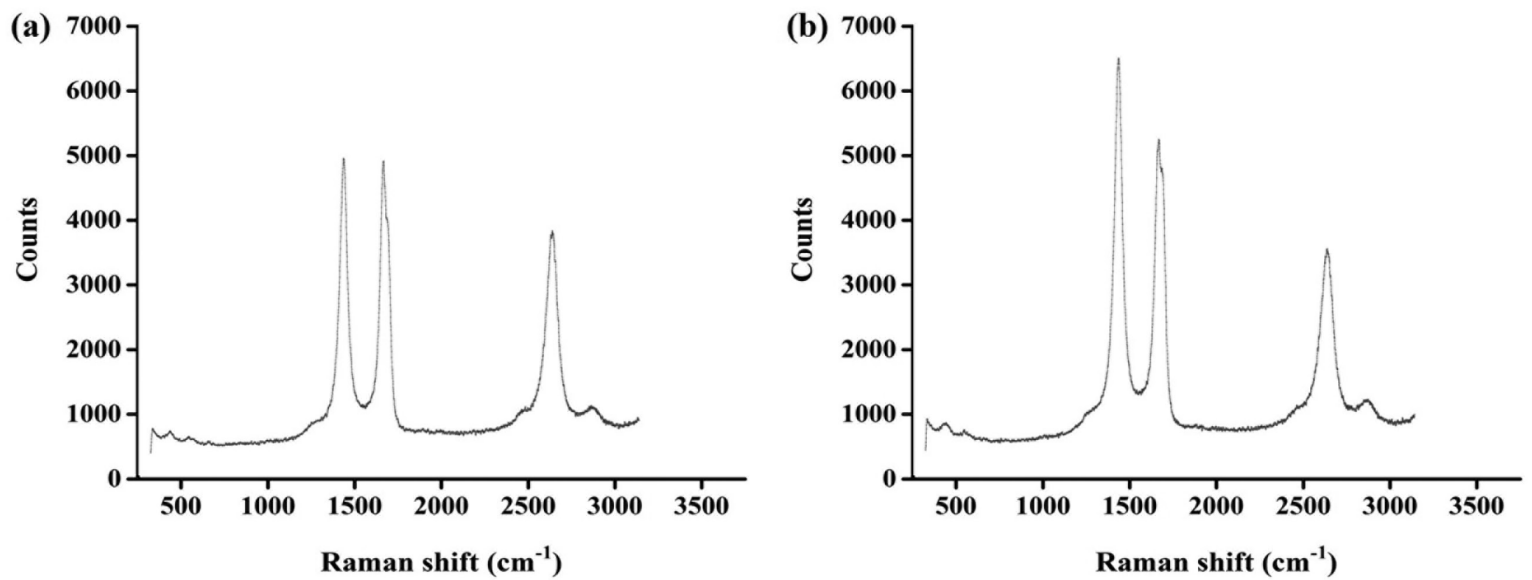

FIGURE 7. Raman spectrum of the synthesized CNTs at (a) $850^{\circ} \mathrm{C} / 180 \mathrm{~min}$ with catalyst feed rate $100 \mathrm{mg} / \mathrm{min}$ (b) $850^{\circ} \mathrm{C} / 60 \mathrm{~min}$ with catalyst feed rate of $100 \mathrm{mg} / \mathrm{min}$

the Raman spectrum of the as-grown MWCNTs synthesized at the reaction time of $60 \mathrm{~min}$. As can be seen, the MWCNTs produced at $800^{\circ} \mathrm{C} / 60$ min have a slightly higher $\mathrm{I}_{\mathrm{D}} /$ $\mathrm{I}_{\mathrm{G}}$ ratio of 0.81 , compared to the MWCNTs produced at $800^{\circ} \mathrm{C} / 180 \mathrm{~min}$. This indicates that more amorphous carbon with residual metal catalyst exist in the structure of MWCNTs confirming the results obtained from other analyses regarding the higher purity of the MWCNTs synthesized at $800^{\circ} \mathrm{C} / 180 \mathrm{~min}$.

\section{XPS ANALYSIS}

The XPS spectra of the MWCNTS were recorded in order to determine the surface composition through the binding energy of photoelectrons; the results of this analysis are depicted in Figure 8 and Table 1. The XPS spectra displayed five peaks showing the elements that present in MWCNTs including carbon $(\mathrm{C})$, cobalt $(\mathrm{Co})$, magnesium $(\mathrm{Mg})$, oxygen $(\mathrm{O})$ and molybdenum $(\mathrm{Mo})$. The peaks for $\mathrm{C} 1 \mathrm{~s}$ and $\mathrm{O} 1 \mathrm{~s}$ were detected at $284.8 \mathrm{eV}$ and $533.1 \mathrm{eV}$, respectively. Figure $8(\mathrm{~b})$ shows that Co $2 \mathrm{p}$ has detectable satellite structures around $784.1 \mathrm{eV}$. The position of peak in the Co $2 p$ spectrum was expected to the presence of cobalt oxide. Similar finding to Larrude (2012), the explanation of cobalt oxides was difficult to accomplish due to the small chemical shift in the XPS spectra of Co $2 p$ electrons in Co $2^{+}$and ${\mathrm{Co} 3^{+}}^{+}$as well as quite identical satellite structures (Larrude et al. 2012). The metal oxides can also be formed directly on the surface of as-produced CNTs. The main benefit of this path is that metal oxide can be deposited as a continuous amorphous or single- crystalline film with controlled thickness, or as discrete units in the form of nanoparticles, nano-rods, or nano-beads. In addition, CNTs can help stabilize unusual or even new crystal phases or prevent crystal growth during crystallization and phase transformation processes (Hu \& Guo 2011). Besides, composite materials based on CNTs and metal oxide nanomaterials integrate the unique features and functions of the two component types and might even exhibit certain new properties caused by mutually supportive effects between the two types of materials.

\section{CONCLUSION}

In this study, MWCNTs were synthesized by CVD method. The effect of reaction time and catalyst feeding rate on the MWCNTs yield and purity was investigated. Both parameters were found to be important for optimum MWCNTs growth. The reaction time of $180 \mathrm{~min}$ and catalyst feeding rate of $100 \mathrm{mg} / \mathrm{min}$ resulted in highest MWCNTs production yield. Analysis of the MWCNTs synthesized at the optimum condition using Raman, TEM, SEM-EDX and TGA confirmed that the MWCNTs produced at $850^{\circ} \mathrm{C} / 180$ min and catalyst feeding rate of $100 \mathrm{mg} / \mathrm{min}$ had the highest purity with less trace of amorphous carbon. This eliminates the need for acid treatment to obtain high purity MWCNTs.

\section{ACKNOWLEDGEMENTS}

The authors gratefully acknowledge the USM-NanoMITE Grant (LRGS): 203/PJKIMIA/6720009 for the financial supports this research.

TABLE 1. XPS surface analysis of MWCNTs

\begin{tabular}{|c|c|c|c|c|c|c|c|c|c|c|}
\hline \multirow[t]{2}{*}{ Sample } & \multicolumn{2}{|c|}{$\mathrm{C} 1 \mathrm{~s}$} & \multicolumn{2}{|c|}{ Co $2 p$} & \multicolumn{2}{|c|}{$\mathrm{Mg} 1 \mathrm{~s}$} & \multicolumn{2}{|c|}{$\mathrm{O} 1 \mathrm{~s}$} & \multicolumn{2}{|c|}{ Mo 3d } \\
\hline & $\begin{array}{c}\text { Atomic } \\
\text { concentration } \\
(\%)\end{array}$ & $\begin{array}{c}\text { Binding } \\
\text { energy } \\
(\mathrm{keV})\end{array}$ & $\begin{array}{c}\text { Atomic } \\
\text { concentration } \\
(\%)\end{array}$ & $\begin{array}{c}\text { Binding } \\
\text { energy } \\
(\mathrm{keV})\end{array}$ & $\begin{array}{c}\text { Atomic } \\
\text { concentration } \\
(\%)\end{array}$ & $\begin{array}{c}\text { Binding } \\
\text { energy } \\
(\mathrm{keV})\end{array}$ & $\begin{array}{c}\text { Atomic } \\
\text { concentration } \\
(\%)\end{array}$ & $\begin{array}{c}\text { Binding } \\
\text { energy } \\
(\mathrm{keV})\end{array}$ & $\begin{array}{c}\text { Atomic } \\
\text { concentration } \\
(\%)\end{array}$ & $\begin{array}{c}\text { Binding } \\
\text { energy } \\
(\mathrm{keV})\end{array}$ \\
\hline MWCNT & 95.16 & 284.1 & 0.24 & 784.1 & 1.19 & 1302.1 & 3.3 & 533.1 & 0.11 & 235.1 \\
\hline
\end{tabular}



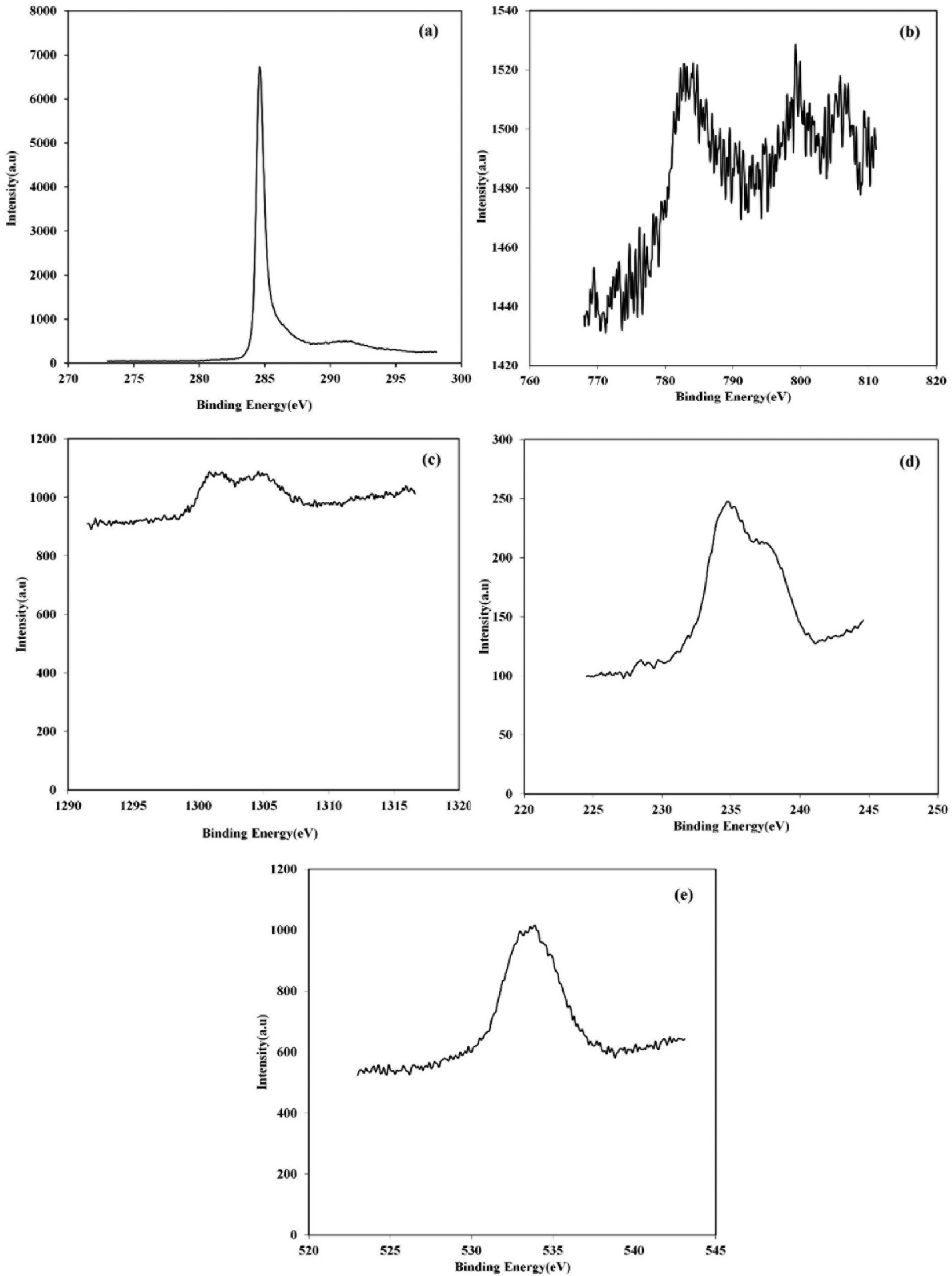

FIGURE 8. The XPS spectra of the CNTs (a) peak of C 1s (b) Co 2p (c) Mg 1s (d) Mo 3d and (e) O $1 \mathrm{~s}$ 


\section{REFERENCES}

Calizo, I., Wenzhong, B., Miao, F., Jeanie, L. \& Alexander, B. 2007. The effect of substrates on the Raman spectrum of graphene: Graphene on-sapphire and graphene-on-glass. Applied Physics Letters 91: 201904.

Chaudhary, K.T., Rizvi, Z.H., Bhatti, K.A., Ali, J. \& Yupapin, P.P. 2013. Multiwalled carbon nanotube synthesis using arc discharge with hydrocarbon as feedstock. Journal of Nanomaterials 2013: 105145.

Dündar-Tekkaya, E. \& Karatepe, N. 2015. Effect of reaction time, weight ratio, and type of catalyst on the yield of single-wall carbon nanotubes synthesized by chemical vapor deposition of acetylene. Fullerenes, Nanotubes and Carbon Nanostructures 23(6): 535-541.

Gulino, G., Vieira, R., Amadou, J., Nguyen, P., Ledoux, M.J., Galvagno, S., Centi, G. \& Pham-Huu, C. 2005. C2H6 as an active carbon source for a large scale synthesis of carbon nanotubes by chemical vapour deposition. Applied Catalysis A: General 279(1-2): 89-97.

Hamedani, Y., Macha, P., Bunning, T.J., Naik, R.R. \& Vasudev, M.C. 2016. Plasma-enhanced chemical vapor deposition: Where we are and the outlook for the future. In Chemical Vapor Deposition - Recent Advances and Applications in Optical, Solar Cells and Solid State Devices, edited by Sudheer Neralla, Ch. 10. Rijeka: InTech.

Hu, Y. \& Guo, C. 2011. Carbon nanotubes and carbon nanotubes/ metal oxide heterostructures: Synthesis, characterization and electrochemical property. In Carbon Nanotubes - Growth and Applications doi: 10.5772/16463.

Jafari, A., Ghoranneviss, M. \& Hantehzadeh, M.R. 2015. Morphology control of graphene by LPCVD. Journal of Fusion Energy 34(3): 532-539.

Kamalakar, G., Hwang, D.W. \& Hwang, L.P. 2002. Synthesis and characterization of multiwalled carbon nanotubes produced using zeolite Co-beta. Journal of Materials Chemistry 12(6): 1819-1823.

Kharlamova, M.V. 2017. Investigation of growth dynamics of carbon nanotubes. Beilstein Journal of Nanotechnology 8: 826-856.

Larrude, D.G., Ayala, P., da Costa, M.E.H. \&. Freire, F.L. 2012. Multiwalled carbon nanotubes decorated with cobalt oxide nanoparticles. Journal of Nanomaterials 2012: Article ID. 695453.

Lu, X., Yim, W.L., Suryanto, B.H.R. \& Zhao, C. 2015. Electrocatalytic oxygen evolution at surface-oxidized multiwall carbon nanotubes. Journal of the American Chemical Society 137(8): 2901-2907.

Mageswari, S., Ahamed, A.J. \& Karthikeyan. S. 2014. Effect of temperature and flow rate on the yield of multi-walled carbon nanotubes by spray pyrolysis using cymbopogen flexuous oil. J. Environ. Nanotechnol. 1(1): 28-31.

Mehra, N.K., Jain, K. \& Kumar, N.J. 2015. Pharmaceutical and biomedical applications of surface engineered carbon nanotubes. Drug Discovery Today 20(6): 750-759.

Ming, H., Peiling, D., Yunlong, Z., Jing, G. \& Xiaoxue, R. 2016. Effect of reaction temperature on carbon yield and morphology of CNTs on copper loaded nickel nanoparticles. Journal of Nanomaterials 2016: Article ID. 8106845.
Monthioux, M. 2011. Introduction to carbon nanotubes. In Carbon Meta-Nanotubes. United Kingdom: John Wiley \& Sons, Ltd. pp. 7-39.

Peng, K., Wan, Y.J., Ren, D.Y., Zeng, Q.W. \& Tang, L.C. 2014. Scalable preparation of multiscale carbon nanotube/glass fiber reinforcements and their application in polymer composites. Fibers and Polymers 15(6): 1242-1250.

Qu, X., Pedro, J.J.A. \& Li, Q. 2013. Applications of nanotechnology in water and wastewater treatment. Water Research 47(12): 3931-3946.

Rouleau, C.M., Tian, M., Puretzky, A.A., Mahjouri-Samani, M., Duscher, G. \& Geohegan, D.B. 2014. Catalytic nanoparticles for carbon nanotube growth synthesized by through thin film femtosecond laser ablation. Proc. of SPIE 8969: 896907.

Shukrullah, S., Mohamed, N.M., Shaharun, M.S. \& Naz, M.Y. 2016. Effect of ethylene flow rate and CVD process time on diameter distribution of MWCNTs. Materials and Manufacturing Processes 31(12): 1537-1542.

Sridhar, S., Ge, L., Tiwary, C.S., Hart, A.C., Ozden, S., Kalaga, K., Lei, S., Sridhar, S.V., Sinha, R.K., Harsh, H., Kordas, K., Ajayan, P.M. \& Vajtai, R. 2014. Enhanced field emission properties from CNT arrays synthesized on inconel superalloy. ACS Applied Materials \& Interfaces 6(3): 1986-1991.

Tran, T.Q., Fan, Z., Liu, P., Sandar, M.M. \& Duong, H.M. 2016. Super-strong and highly conductive carbon nanotube ribbons from post-treatment methods. Carbon 99: 407-415.

Vilatela, J.J., Rabanal, M., Cervantes-Sodi, F., García-Ruiz, M., Jiménez-Rodríguez, J.A., Reiband, G. \& Terrones, M. 2015. A spray pyrolysis method to grow carbon nanotubes on carbon fibres, steel and ceramic bricks. Journal of Nanoscience and Nanotechnology 15: 2858-2864.

Yeoh, W.M., Lee, K.T., Abdul, Mohamed. \& Siang-Piao, C. 2012. Production of carbon nanotubes from chemical vapor deposition of methane in a continuous rotary reactor system. Chemical Engineering Communications 199(5): 600-607.

Yoon, D. \& Hyeonsik, C. 2012. Raman spectroscopy for characterization of graphene. In Raman Spectroscopy for Nanomaterials Characterization, edited by Challa, S.S.R.K. Berlin, Heidelberg: Springer Berlin Heidelberg. pp. 191-214.

Zhang, Q., Huang, J.Q., Qian, W.Z., Zhang, Y.Y. \& Fei, W. 2013. The road for nanomaterials industry: A review of carbon nanotube production, post-treatment, and bulk applications for composites and energy storage. Small 9(8): 1237-1265.

School of Chemical Engineering

Universiti Sains Malaysia

14300 NIibong Tebal, Pulau Pinang

Malaysia

*Corresponding author; email: chrahman@usm.my

Received: 13 August 2018

Accepted: 3 December 2018 